Purwanto · B.R. Wijonarko · Tarjoko

\title{
Perubahan karakter biokimia dan fisiologi tanaman kacang hijau pada berbagai kondisi cekaman kekeringan
}

\section{Changes in biochemical and physiology characters of mungbean in drought stress conditions}

Diterima : 2 Desember 2018/Disetujui : 28 Maret 2019 / Dipublikasikan : 31 Maret 2019

CDepartment of Crop Science, Padjadjaran University

\begin{abstract}
This study aims to examine the physiological and biochemical responses of mungbean plants to drought stress. The research was conducted at the Screen House Exfarm, Faculty of Agriculture, Jenderal Soedirman University, Purwokerto, from March to October 2018. Experiment used Randomized Block Design with factorial treatment. The first factor was the level of soil moisture, consisted of level of $100 \%$ field capacity as control, $75 \%$ field capacity, and $50 \%$ field capacity. The second factor was the superior varieties of mungbeans, consisted of Vima 2, Vima 3, and Kutilang varieties. The results showed that drought stress up to 50 percent of field capacity had shown a decrease in the character of leaf area and dry weight of plants, but it had not affected the prolin content of mungbean plants.
\end{abstract}

Keywords: Mungbean • Drought stress • Variety • Biochemistry • Physiology

Sari. Penelitian ini bertujuan untuk mengkaji respons fisiologi dan biokimia tanaman kacang hijau terhadap cekaman kekeringan. Penelitian dilaksanakan di Screen House Exfarm Fakultas Pertanian Universitas Jenderal Soedirman Purwokerto dari bulan Maret sampai dengan Oktober 2018. Rancangan percobaan yang digunakan adalah Rancangan Acak Kelompok (RAK) dengan pola faktorial $3 \times 3$. Faktor pertama yang dicoba adalah tingkat kelengasan tanah, yakni kadar air kapasitas lapang sebagai kontrol, 75\% kapasitas lapang, dan 50\% kapasitas lapang. Faktor kedua adalah varietas unggul kacang hijau

\footnotetext{
Dikomunikasikan oleh Aep Wawan Irwan

Purwanto $^{1}$ B.R. Wijonarko ${ }^{1}$ Tarjoko $^{1}$

Departemen Agroteknologi Fak. Pertanian UNSOED

Purwokerto

Jl. Dr. Suparno KP. 125 Purwokerto Jawa Tengah

Korespondensi : purwanto.unsoed@gmail.com
}

yang terdiri dari Varietas Vima 2, varietas Vima 3, dan Varietas Kutilang. Hasil penelitian menunjukkan bahwa cekaman kekeringan sampai 50 persen kapasitas lapang sudah menunjukkan penurunan pada karakter luas daun dan bobot kering tanaman, tetapi belum berpengaruh terhadap kadar prolin tanaman kacang hijau.

Kata kunci: Kacang hijau • Cekaman kekeringan • Varietas • Biokimia · Fisiologi

\section{Pendahuluan}

Kacang hijau merupakan salah satu komoditas palawija yang memiliki potensi ekonomi yang tinggi dan sumber protein bagi masyarakat. Hal ini menjadi alternatif sumber protein dan kalori yang selama ini didominasi oleh kelompok tanaman serealia (Kasno et al., 2008). Petani pada umumnya menanam kacang hijau sebagai tanaman sela pada lahan sawah setelah panen padi musim tanam (MT) 2 dengan metode tanpa olah tanah, tanpa pengairan, dan tanpa pemupukan. Menurut Kasno (2007) produksi nasional kacang hijau $70 \%$ berasal dari produksi kacang hijau yang dibudidayakan di lahan sawah.

Potensi lahan kering setelah tanam padi tersedia sangat besar, sehingga potensial untuk pengembangan tanaman kacang hijau. Produktivitas kacang hijau di lahan sawah ratarata 1,16 ton.ha- ${ }^{-1}$, masih di bawah potensi genetis yang mencapai 2 ton.ha- ${ }^{-1}$ (Trustinah et al., 2014). Hambatan utama pengembangan kacang hijau di lahan kering adalah ancaman kekeringan sehingga produktivitas rendah. Lahan kering mempunyai permasalahan ancaman kekeringan, miskin unsur hara, dan pH tanah rendah (Kasno, 2007; Trustinah et al., 2014). 
Pergeseran musim akibat perubahan iklim global telah menyebabkan pergeseran musim tanam padi sehingga berdampak pada mundurnya musim panen padi. Musim panen MT 2 di Jawa Tengah pada umumnya jatuh pada bulan Juni, sehingga musim tanam kacang hijau mulai pada awal Juni - Juli. Ariyanto (2010) melaporkan bahwa volume curah hujan bulan Mei sangat mempengaruhi produktivitas kacang hijau yang ditanam pada musim tanam kedua di lahan kering. Petani pada umumnya menggunakan varietas lokal dengan umur panjang dan fase pemasakan polong tidak serempak, sehingga berpotensi mengalami cekaman kekeringan lebih lama. Guntoro dan Suhartono et al., (2008) melaporkan bahwa tanaman kedelai yang mengalami cekaman kekeringan sampai 25\% kapasitas lapang menyebabkan pertumbuhan tanaman sangat terganggu terutama pertumbuhan daun. Rahbarian, et. al., (2011) juga menyatakan bahwa cekaman kekeringan secara nyata menurunkan biomassa tanaman, laju asimilasi $\mathrm{CO}_{2}$, dan laju transpirasi tanaman, serta kehilangan hasil pada tanaman kedelai bisa mencapai $43-44 \%$ (Kobraei, et. al., 2011).

Pada kondisi cekaman kekeringan, tanaman meningkatkan daya tahannya baik secara morfologi, fisiologi, seluler maupun molekuler (Fang dan Xiong, 2015). Wang, et. al., (2015) menyatakan bahwa pada kondisi cekaman kekeringan, fotosintesis tanaman cenderung menurun, serta perubahan hormonal (auxin, sitokinin dan ABA) menyebabkan menutupnya stomata, mengurangi pembelahan dan pengembangan sel sebagai upaya adaptasi tanaman. Respons biokimia tanaman terhadap cekaman kekeringan dengan meningkatkan senyawa prolin sebagai osmoprotektan untuk mempertahankan potensial osmotik dalam tanaman (Kurniawati et al., 2014). Riduan et al., (2005) melaporkan bahwa kultivar kacang tanah yang toleran cekaman kekeringan mampu mengakumulasi prolin dalam daun dengan cepat antara $177 \%$ sampai $242 \%$ dibandingkan kultivar yang tidak toleran.

Dalam pengembangan produksi kacang hijau, varietas tanaman merupakan salah satu faktor produksi yang sangat penting. Ketersediaan varietas unggul sampai saat ini sudah tersedia 20 kultivar (Trustinah et al., 2014), namun dalam menghadapi perubahan iklim terutama ancaman cekaman kekeringan pada budidaya kacang hijau di lahan sawah sangat diperlukan varietas unggul yang tahan terhadap kekeringan. Oleh karena itu, penggunaan kultivar yang tahan terhadap cekaman kekeringan sangat diperlukan terutama kultivar yang mempunyai potensi hasil tinggi. Tujuan penelitian ini adalah mengkaji respons fisiologi dan biokimia tanaman kacang hijau terhadap cekaman kekeringan; dan mengkaji seberapa besar pengaruh cekaman kekeringan terhadap penurunan produkstivitas tanaman kacang hijau.

\section{Bahan dan Metode}

Percobaan dilaksanakan di Screen House Exfarm, Fakultas Pertanian, Universitas Jenderal Soedirman, Purwokerto, dari bulan Maret sampai dengan Oktober 2018, pada ketinggian tempat $100 \mathrm{~m} \mathrm{dpl}$, dengan jenis tanah Inceptisol. Bahan yang dibutuhkan dalam percobaan ini antara lain benih kacang hijau (Varietas Kutilang, Vima 2, dan Vima 3), pupuk Urea, SP36, $\mathrm{KCl}$, aseton, bahan kimia untuk analisis prolin, kertas saring, alkohol $70 \%$, kutek clear, dan aquades. Alat yang dibutuhkan dalam percobaan ini antara lain plastik, ember, selang plastik, kantong plastik, timbangan, timbangan analitik, tabung ukur, becker gelas, inkubator, erlemyer, tabung reaksi, tabung sentrifugal, sentrifugal, corong kaca, spektrofotometer, waterbath, leaf area meter, mikroskop binokuler, kaca objek, selotip, makro pipet, dan oven.

Percobaan ini menggunakan metode eksperimen di rumah kaca, dengan Rancangan Acak Kelompok (RAK) pola faktorial 3 X 3. Faktor pertama adalah tingkat kelengasan tanah yakni $c_{0}$ (kadar air kapasitas lapang sebagai kontrol), c 1 (75\% kapasitas lapang) dan $\mathrm{c}_{2}(50 \%$ kapasitas lapang). Faktor kedua adalah varietas unggul kacang hijau yang terdiri dari $\mathrm{v}_{1}$ (Varietas Vima 2), $v_{2}$ (varietas Vima 3), dan v3 (Varietas Kutilang). Kombinasi perlakuan yang diperoleh sebanyak 9 kombinasi perlakuan, dan diulang sebanyak tiga kali sehingga diperoleh 27 unit percobaan. Setiap unit percobaan terdiri dari 8 polibag.

Benih kacang hijau ditanam dalam polibag sebanyak 2 biji per polibag, setelah dua minggu setelah tanam (MST) dilakukan penjarangan dengan menyisakan satu tanaman per polibag. Tanaman dipelihara dengan pengairan optimum (kapasitas lapang) sampai umur 4 MST, kemudian kadar air media dibiarkan turun 
sampai sesuai dengan perlakuan dengan dipertahankan konstan dengan mempertahankan berat polibag.

Variabel pertumbuhan yang diamati antara lain luas daun trifoliate, lebar bukaan stomata, kerapatan stomata, dan bobot kering brangkasan. Lebar bukaan dan kerapatan stomata diamati dengan metode imprint (Adisyahputra, et. al., 2011). Variabel hasil dan komponen hasil yang akan diamati meliputi jumlah polong per tanaman, jumlah biji per polong, bobot 100 biji (g), dan bobot biji per tanaman (g). Karakter fisiologis yang diamati antara lain laju asimilasi bersih (LAB). LAB dihitung berdasarkan formula (Gardner, et. al., 1991).

\section{$\mathrm{LAB}=\left(\mathrm{W}_{2}-\mathrm{W}_{1}\right) /\left(\mathrm{T}_{2}-\mathrm{T}_{1}\right) \times\left(\ln \mathrm{L}_{\mathrm{a} 2}-\ln \mathrm{L}_{\mathrm{a} 1}\right) /\left(\mathrm{L}_{\mathrm{a} 2}-\mathrm{L}_{\mathrm{a} 1}\right)$}

Keterangan : $\mathrm{W}_{2}$ dan $\mathrm{W}_{1}$ masing-masing adalah bobot kering tanaman akhir dan awal, $\mathrm{La}_{2}$ dan $\mathrm{La}_{1}$ masing-masing adalah luas daun tanaman akhir dan awal, $\mathrm{T}_{2}-\mathrm{T}_{1}$ adalah selang waktu pengamatan bobot kering tanaman.

Karakter biokimia yang diamati antara lain kandungan klorofil a dan klorofil $b$ daun, dan kadar prolin daun. Kandungan klorofil daun diukur dengan metode kolorimetri dengan spektrofotometer (Holden, 1965 dalam Proklamasiningsih et al., 2012). Daun ditimbang seberat $0,1 \mathrm{~g}$, dipotong kecil-kecil dan ditumbuk dengan mortar sampai halus, ditambah $10 \mathrm{~mL}$ aceton $80 \%$, kemudian disaring dan dimasukkan ke dalam tabung reaksi, diambil 10 mL larutan, dan dimasukan dalam cuvet untuk diukur absorbansinya dengan spektrofotometer (Thermo Scientific Genesis 20) pada $\lambda 645$ dan 663 $\mathrm{nm}$. Kadar klorofil dihitung dengan rumus :

$$
\begin{aligned}
& \begin{array}{l}
\text { Klorofil } \mathrm{a}=0,0127(\mathrm{OD} 663)-0,00269 \\
(\mathrm{mg} / \mathrm{g})
\end{array} \\
& \begin{array}{l}
\text { Klorofil } \mathrm{b}=0,0229(\mathrm{OD} 645) \\
(\mathrm{mg} / \mathrm{g})
\end{array} \\
& \begin{array}{l}
\text { Klorofil total }=0,0202(\mathrm{OD} 645)-0,00468(\mathrm{OD} 663) \\
663)(\mathrm{mg} / \mathrm{g})
\end{array}
\end{aligned}
$$

Kandungan prolin diukur menggunakan metode Magna dan Larher (1984) dalam Nikmatullah (2010). Sampel daun seberat $50 \mathrm{mg}$ digiling halus dengan nitrogen cair, kemudian dimasukan kedalam tabung Effendorf, dan dilarutkan dengan 1,2 $\mathrm{mL}$ larutan sulphosalicylic acid $3 \%(\mathrm{w} / \mathrm{v})$. Tabung diforteks selama 30 detik, dan disentrifugasi pada kecepatan 20.800x gravitasi selama 7 menit pada suhu $4{ }^{\circ} \mathrm{C}$. Supernatant dipindahkan ke tabung Falcon, dan diencerkan dua kali lalu diekstrak dengan buffer ekstraksi (1:2, v/v) [ninhydrin 1\% $(\mathrm{w} / \mathrm{v})$ dalam GAA 60\% (v/v)]. Tabung diinkubasikan pada suhu $98{ }^{\circ} \mathrm{C}$ selama 1 jam, lalu segera didinginkan (diletakkan pada serutan es), dan prolin diekstrak dengan menambahkan toluene $(1: 1, \mathrm{v} / \mathrm{v})$ lalu dicampur dengan cara diforteks, dibiarkan selama 5 menit dan selanjutnya fase atas (toluena dan prolin) diambil dan dibaca absorban-nya pada panjang gelombang $518 \mathrm{~nm}$, setelah dinormalisasi dengan toluena murni. Konsentrasi prolin dihitung dari persamaan yang telah dibuat menggunakan persamaan regresi linier dari prolin standar.

Data yang diperoleh kemudian dianalisis dengan menggunakan uji $\mathrm{F}$, dan apabila berbeda nyata dilanjutkan dengan uji Duncan pada taraf kepercayaan $95 \%$.

\section{Hasil dan Pembahasan}

\section{Pengaruh Cekaman Kekeringan terhadap} Karakter biokimia dan fisiologi tanaman kacang hijau. Hasil penelitian menunjukkan antar varietas tanaman kacang hijau terlihat perbedaan luas daun sampai umur 63 hst. Secara morfologi, luas daun varietas Vima III cenderung menunjukkan luas daun terluas jika dibandingkan varietas Kutilang maupun Vima II masing-masing sebesar 213,36, 223,69, dan 436,55 cm² (Gambar 1). Tingkat cekaman kekeringan sampai 50 persen kapasitas lapang secara nyata menurunkan luas daun total tanaman kacang hijau (Gambar 2). Luas daun pada kadar air tanah $75 \%$ kapasitas lapang cenderung menunjukkan luas daun total yang terbesar lebih tinggi dibanding pada kondisi kapasitas lapang, tetapi luas daun kacang hijau menurun ketika kadar air tanah diturunkan sampai 50\% kapasitas lapang. Penurunan luas daun total pada kadar air tanah 50\% kapasitas lapang sebesar 14,73 persen terhadap kondisi kapasitas lapang.

Pada kondisi cekaman kekeringan, tanaman akan beradaptasi dengan mengurangi luas daun untuk menekan laju transpirasi sehingga tanaman tidak mengalami kekurangan air. Hal ini akan berpengaruh terhadap proses fotosintesis tanaman menurun, meskipun variabel yang mendukung fotosintesis seperti 
kerapatan, dan lebar bukaan stomata pada tanaman kacang hijau tidak menunjukkan perbedaan yang nyata baik antar varietas maupun pada berbagai kondisi kadar air tanah (Gambar 3). Tanaman kacang hijau relatif tahan terhadap kekeringan dimana penurunan kadar air sampai $25 \%$ dari kapasitas lapang justru menunjukkan luas daun yang lebih luas, hal ini akan sangat berbeda pada tanaman lainnya seperti kedelai. Pada tanaman kedelai, lebar pembukaan stomata semakin kecil seiring penambahan taraf cekaman kekeringan, yaitu dari kadar air kapasitas lapang, 60\% kapasitas lapang dan paling rendah dicapai pada $40 \%$ kapasitas lapang (Purwanto dan Agustono, 2010).

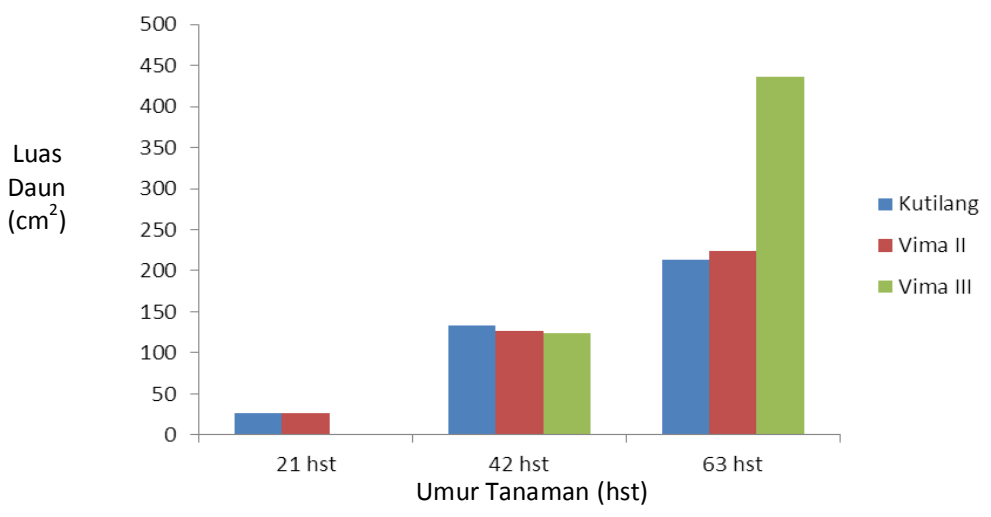

Gambar 1. Luas Daun Beberapa Varietas Kacang Hijau.

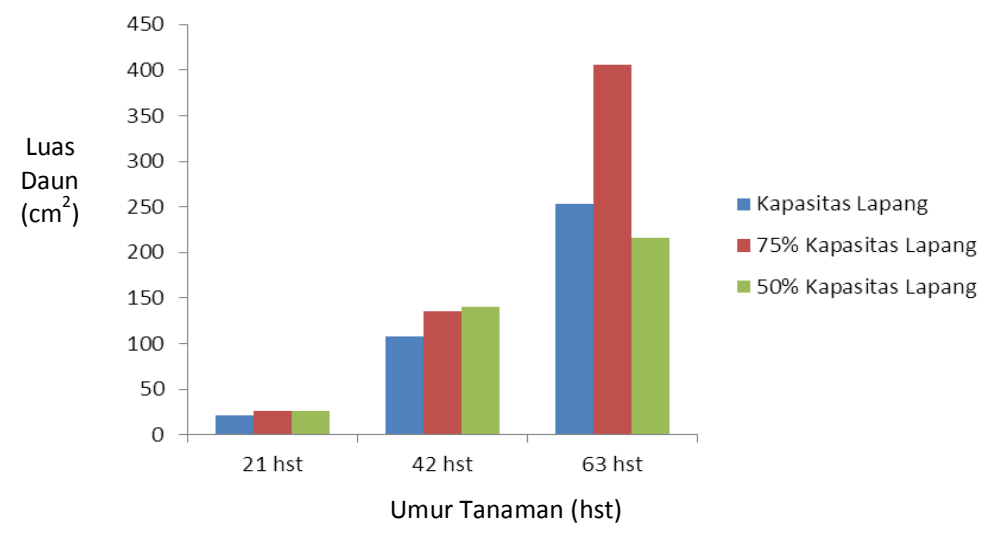

Gambar 2. Luas Daun Tanaman Kacang Hijau pada Berbagai Kadar Lengas Tanah.

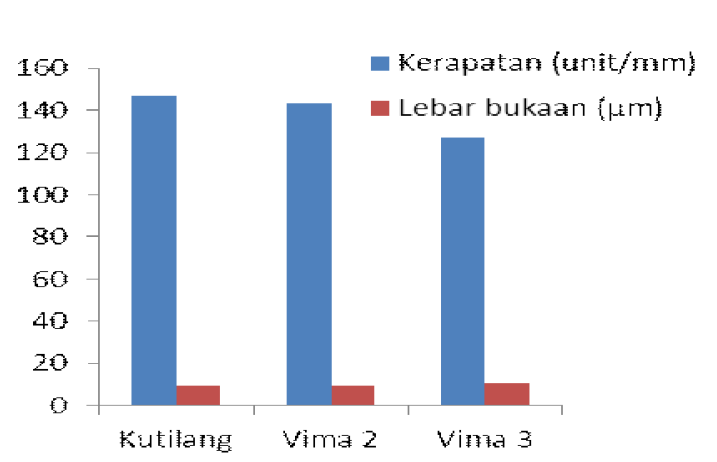

A

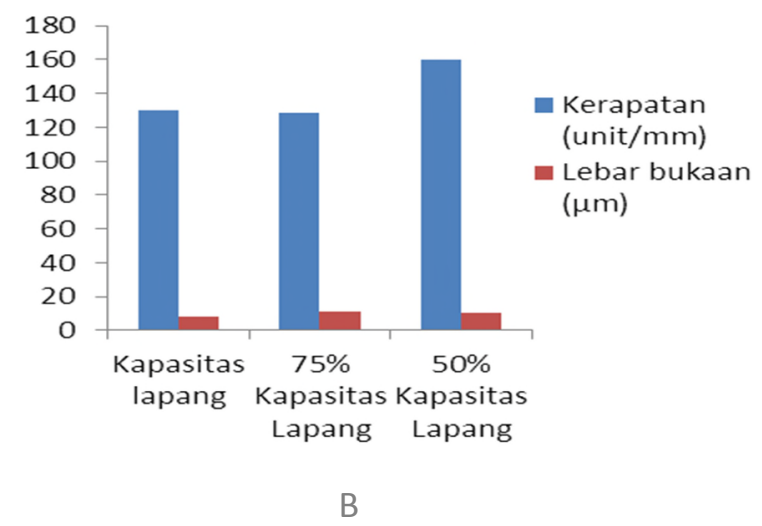

Gambar 3. A. Lebar Bukaan Stomata dan Kerapatan Stomata Beberapa Varietas Kacang Hijau, B. Lebar Bukaan Stomata dan Kerapatan Stomata Tanaman Kacang Hijau pada Berbagai Cekaman Kekeringan 
Bobot kering tanaman antar varietas kacang hijau sampai umur umur tanaman 63 hst menunjukkan perbedaan yang nyata (Gambar 4). Varietas Vima III memiliki bobot kering tanaman tertinggi sebesar 4,12 g, berbeda nyata dengan Varietas Vima II dan Varietas Kutilang masingmasing sebesar 2,32 g dan 1,93 g. Keragaan karakter morfologi tanaman pada berbagai varietas merupakan karakter yang menjadi pembeda antar varietas. Antar varietas terdapat keragaman penampilan tanaman sehingga menimbulkan perbedaan sifat tanaman baik bentuk maupun fungsi yang mendukung pertumbuhan tanaman (Sitompul dan Guritno, 1995).

Cekaman kekeringan belum berpengaruh terhadap bobot kering tanaman sampai umur 63 hst, dimana cekaman kekeringan sampai 50 persen kapasitas lapang cenderung memberikan nilai terendah sebesar 1,94 $\mathrm{g}$, disusul kapasitas lapang dan kadar air 75 persen masing-masing sebesar 2,05 g dan 4,39 g (Gambar 5). Bobot kering tanaman merupakan gambaran besarnya akumulasi asimilat yang dihasilkan oleh tanaman. Bobot kering tanaman merupakan hasil fotosintesis sebagai proses asimilasi karbon dari $\mathrm{CO}_{2}$ yang diamnbil tanaman melalui stomata. Hasil biomassa yang tidak berbeda disebabkan oleh beberapa variabel yang mendukung terhadap proses fotosintesis dimana luas daun tanaman, lebar bukaan stomata dan kerapatan stomata tanaman kacang hijau pada berbagai cekaman kekeringan juga menunjukkan tidak ada perbedaan. Purwaningrahayu, et. al., (2011) menyatakan bahwa pada kondisi cekaman kekeringan, metabolisme tanaman khususnya akan terganggu apabila stomata sebagai tempat untuk pertukaran gas dan $\mathrm{CO}_{2}$ terganggu terlebih dahulu, namun demikian hasil penelitian ini menunjukkan bahwa lebar bukaan stomata maupun kerapatan stomata tidak berbeda pada kondisi cekaman kekeringan sampai 50 persen sehingga masih mampu untuk mensuplai karbon dalam proses fotosintesis. Hal ini menunjukkan hal yang berbeda dengan tanaman kedelai dimana melaporkan bahwa cekaman kekeringan menurunkan biomassa tanaman, laju asimilasi $\mathrm{CO}_{2}$, dan laju transpirasi tanaman, serta kehilangan hasil pada tanaman kedelai mencapai 44 persen (Kobraei et al., 2011; dan Rahbarian et al., 2011)
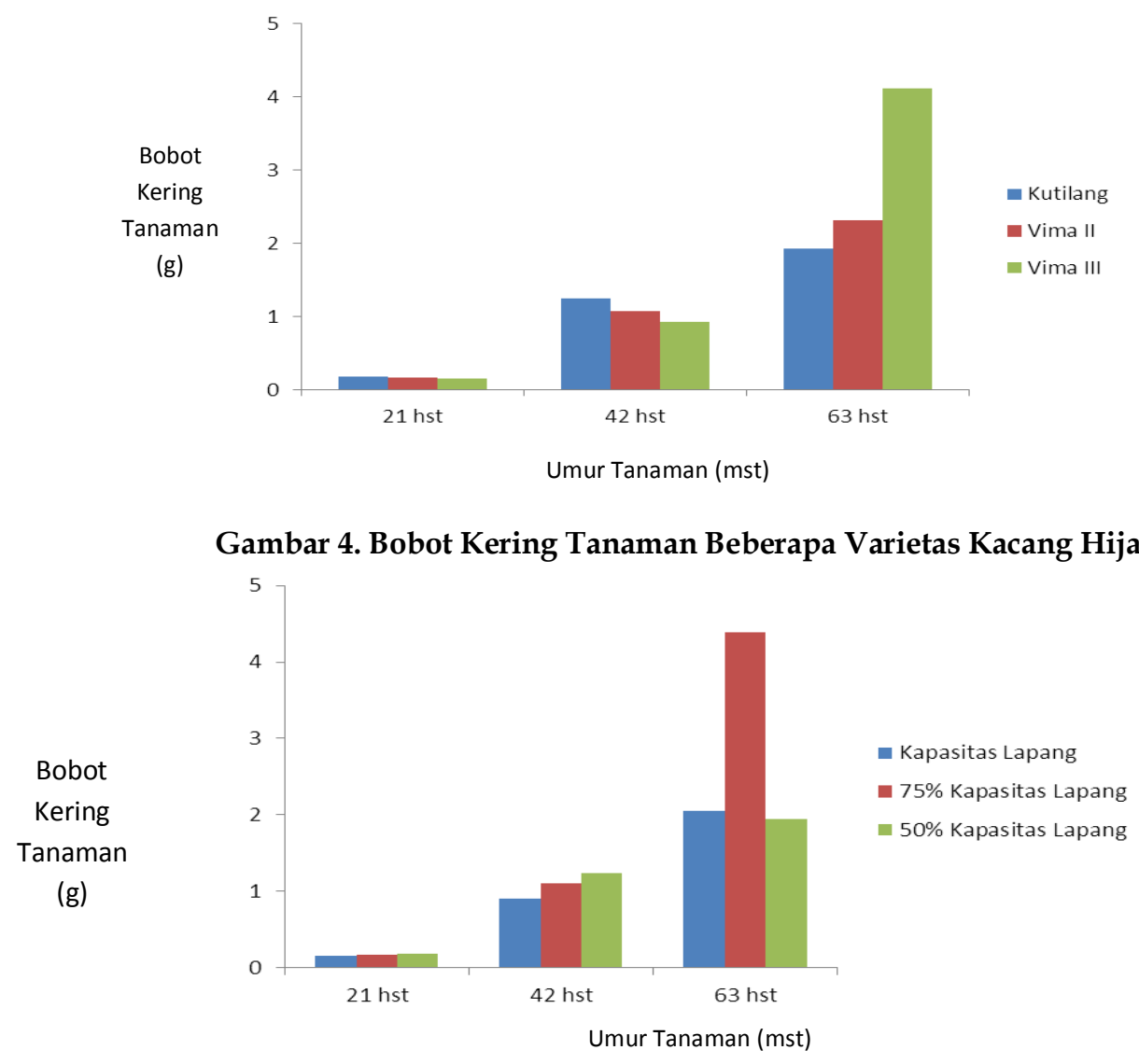

Gambar 5. Bobot Kering Tanaman Kacang Hijau pada Kondisi Cekaman Kekeringan. 
Tabel 1. Pengaruh Cekaman Kekeringan dan Varietas Kacang Hijau Terhadap Laju Asimilasi Bersih.

\begin{tabular}{lcccc}
\hline \multirow{2}{*}{ Cekaman } & \multicolumn{4}{c}{. Laju asimilasi bersih $\left(\mathrm{g} / \mathrm{cm}^{2} / \mathrm{minggu}\right)$} \\
\cline { 2 - 5 } & Kutilang & Vima II & Vima III & Rerata \\
\hline Kapasitas lapang & 0,71 & 0,71 & 0,72 & $0,71 \mathrm{a}$ \\
75 persen kapasitas lapang & 0,71 & 0,72 & 0,72 & $0,72 \mathrm{a}$ \\
50 persen kapasitas lapang & 0,71 & 0,70 & 0,72 & $0,71 \mathrm{a}$ \\
\hline \multicolumn{1}{c}{ Rerata } & $0,71 \mathrm{a}$ & $0,71 \mathrm{a}$ & $0,72 \mathrm{a}$ & \\
\hline
\end{tabular}

Keterangan: Angka-angka yang diikuti oleh huruf yang sama pada kolom yang sama menunjukkan tidak berbeda nyata menurut Uji DMRT pada taraf kepercayaan $95 \%$

Cekaman kekeringan sampai 50\% kapasitas lapang pada beberapa varietas tanaman kacang hijau belum menunjukkan perbedaan dilihat dari variabel laju asimilasi bersih (LAB). Laju asimilasi bersih terbesar pada varietas Vima 3 $(0,72)$ dan paling kecil pada varietas Kutilang $(0,71)$ namun tidak berbeda nyata satu sama lain (Tabel 1). Perlakuan cekaman kekeringan tidak berpengaruh nyata terhadap laju asimilasi bersih, dimana laju asimilasi bersih terbesar pada kadar lengas tanah $75 \%$ kapasitas lapang $(0,71)$ dan paling kecil pada kadar lengas tanah $50 \%$ kapasitas lapang (0,71). Cekaman kekeringan menyebabkan pasokan air dari akar akan berkurang untuk disuplai ke duan sehingga menyebabkan pproses asimilasi karbon menurun. Hal ini diperkuat dengan pendapat Suhartono, et. al., (2008) yang menyatakan bahwa cekaman kekeringan menurunkan pertumbuhan dan laju fotosintes sehingga tanaman menjadi kerdil.

Karakter biokimia tanaman kacang hijau pada berbagai cekaman kekeringan tidak menunjukkan perbedaan terutama untuk karakter kadar klorofil a dan klorofil b, namun demikian kadar prolin daun antar varietas menunjukkan perbedaan (Tabel 2 dan Gambar 6). Penurunan kadar air tanah sampai 50 persen kapasitas lapang diduga belum menimbulkan dampak stress kekeringan terhadap tanaman kacang hijau, sehingga respons adaptasi secara biokimia belum terlihat. Karakter yang sangat sensitif terhadap perubahan kelengasan tanah adalah prolin. Prolin digunakan sebagai indikator toleransi terhadap cekaman kekeringan, dimana struktur prolin yang hidrofobik mampu mengikat protein disamping mengikat air sehingga protein mampu meningkatkan kelarutannya dan menjaga dari denaturasi protein (Fang and Xiong, 2015). Menurut Farooq et al., (2009) akumulasi prolin dan zat terlarut menyebabkan potensial osmotik sel menurun, dan menarik air ke dalam sel dan membantu pemeliharaan turgor sel. Varietas Vima III diduga merupakan varietas yang lebih tahan terhadap kekeringan jika dibandingkan dengan varietas Kutilang maupun Vima II. Kadar prolin daun varietas Vima III menunjukkan nilai tertinggi yakni $17.14 \mu \mathrm{mol}$ prolin. Nilai ini jauh lebih besar $48.83 \%$ jika dibandingkan varietas Vima II, dan 33.96 persen lebih besar dibanding varietas Kutilang.

Strategi adaptasi secara biokimia pada berbagai tanaman dalam kondisi cekaman kekeringan melalui sintesis dan mengakumulasi osmoprotektan dan osmolytes. Osmoprotektan pada umumnya adalah senyawa dengan berat molekul rendah, tidak beracun dan konsentrasi tinggi seperti gula terlarut, gula alkohol, prolin, glycinebetaine, asam organik, kalsium, potasium, ion klorida (Farooq et al., 2009). Menurut Farooq et al., (2009) akumulasi prolin dan zat terlarut menyebabkan potensial osmotik sel menurun, dan menarik air ke dalam sel dan membantu pemeliharaan turgor sel. Alexieva, et. al., (2001) melaporkan bahwa pada tanaman kacang polong cekaman kekeringan menekan aktivitas enzim katalase dan superoksida dismutase, serta meningkatkan aktivitas peroksidase, tetapi pada tanaman gandung justru menekan aktivitas enzim tersebut, dan akumulasi prolin pada tanaman tersebut meningkat. Boroowa and Gogoi (2013) juga melaporkan bahwa terjadi peningkatan akumulasi prolin pada Vigna radiate L. dan Vigna mungo L.

Hasil dan Komponen Hasil Varietas Kacang Hijau pada Berbagai Cekaman Kekeringan. Hasil penelitian menunjukkan bahwa perlakuan cekaman kekeringan berpengaruh nyata terhadap jumlah polong pertanaman, sedangkan varietas dan interaksi antara cekaman kekeringan dan varietas tidak berbeda nyata terhadap parameter jumlah polong per tanaman. Varietas yang diuji tidak menunjukkan pengaruh nyata terhadap jumlah polong per tanaman dimana jumlah polong per tanaman terbanyak pada varietas Vima $3(8,92$ 
polong) dan paling sedikit pada varietas Vima 2 (7,92 polong). Jumlah polong per tanaman terbanyak pada perlakuan kadar lengas kapasitas lapang $(9,40$ polong $)$ dan paling sedikit pada kadar lengas tanah 50\% kapasitas lapang (7 polong).

Tabel 2. Pengaruh Kadar Kelengasan Tanah dan Varietas Kacang Hijau terhadap Klorofil Tanaman Kacang Hijau.

\begin{tabular}{lcc}
\hline \multicolumn{1}{c}{ Perlakuan } & $\begin{array}{c}\text { Klorofil a } \\
(\mathrm{mg} / \mathrm{g})\end{array}$ & $\begin{array}{c}\text { Klorofil b } \\
(\mathrm{mg} / \mathrm{g})\end{array}$ \\
\hline Kutilang & $0,01 \mathrm{a}$ & $0,005 \mathrm{a}$ \\
Vima 2 & $0,02 \mathrm{a}$ & $0,006 \mathrm{a}$ \\
Vima 3 & $0,01 \mathrm{a}$ & $0,004 \mathrm{a}$ \\
Kapasitas lapang & $0,013 \mathrm{a}$ & $0,0051 \mathrm{a}$ \\
75\% Kapasitas & $0,015 \mathrm{a}$ & $0,0055 \mathrm{a}$ \\
Lapang & & \\
50\% Kapasitas & $0,014 \mathrm{a}$ & $0,0055 \mathrm{a}$ \\
Lapang & &
\end{tabular}

Keterangan : Angka-angka yang dikuti oleh huruf yang sama pada kolom dan perlakuan yang sama tidak berbeda nyata menurut uji DMRT pada taraf kepercayaan $95 \%$.

Jumlah polong yang terbentuk berkaitan dengan jumlah bunga yang mampu melakukan fertilisasi dan membentuk polong. Pada kondisi kekeringan, dampak langsung yang mengenai tanaman pada fase generatif adalah kegagalan bunga untuk fertilisasi dan gugur. Lebih lanjut
Liu et al., (2004) menyatakan bahwa cekaman kekeringan akan menyebabkan menurunnya potensial air sehinigga metabolisme karbohidrat rendah di dalam polong dan menyebabkan polong gugur. Frederick et al., (2001) melaporkan bahwa tanaman kedelai yang mengalami cekaman kekeringan berdampak terhadap kemampuan tanaman untuk berfotosintesis, sehingga laju pertumbuhan menurun antara fase $\mathrm{R}_{1}$ dan $\mathrm{R}_{5}$ sehingga menurunkan jumlah polong dan jumlah biji sehingga produksi menurun

Tabel 3. Pengaruh Cekaman Kekeringan dan Varietas Kacang Hijau Terhadap Jumlah Polong Per Tanaman.

\begin{tabular}{lcccc}
\hline & \multicolumn{4}{c}{ Varietas } \\
\cline { 2 - 5 } Cekaman & Kutilang & Vima II & Vima 3 & Rerata \\
\hline Kapasitas & 9,33 & 8,33 & 10,55 & $9,40 \mathrm{a}$ \\
lapang & 8,33 & 8,77 & 8,44 & $8,51 \mathrm{ab}$ \\
$\begin{array}{l}75 \text { persen } \\
\text { kapasitas } \\
\text { lapang }\end{array}$ & & & & \\
$\begin{array}{l}50 \text { persen } \\
\text { kapasitas } \\
\text { lapang }\end{array}$ & 6,55 & 6,66 & 7,77 & $7 \mathrm{~b}$ \\
\hline Rerata & $8,07 \mathrm{a}$ & $7,92 \mathrm{a}$ & $8,92 \mathrm{a}$ \\
\hline
\end{tabular}

Keterangan: Angka-angka yang diikuti oleh huruf yang sama pada kolom yang sama menunjukkan tidak berbeda nyata menurut Uji DMRT pada taraf kepercayaan $95 \%$.

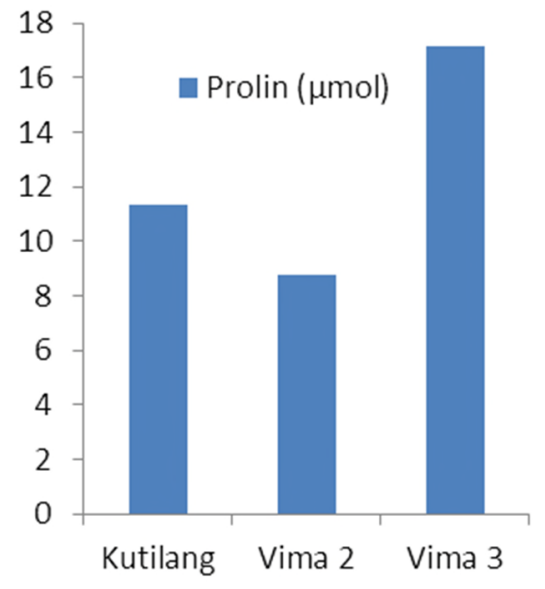

A

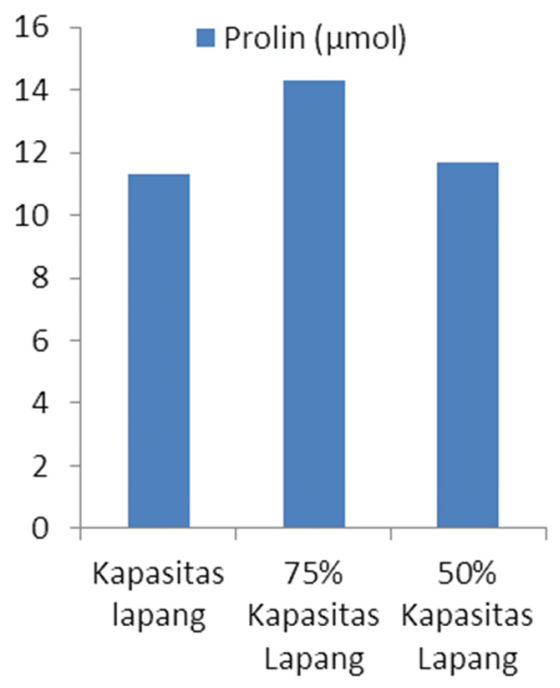

B

Gambar 6. A. Kadar Prolin Daun Beberapa Varietas Kacang Hijau, B. Kadar Prolin Daun Tanaman Kacang Hijau pada Berbagai Cekaman Kekeringan. 
Hasil penelitian menunjukkan bahwa antar varietas yang diuji menunjukan perbedaan yang sangat nyata pada variabel jumlah biji per polong, bobot biji per tanaman dan bobot 100 biji. Jumlah biji per polong terbanyak pada varietas Vima $3(10,62)$ dan paling sedikit pada varietas Kutilang $(8,51)$, sedangkan bobot biji per tanaman tertinggi dicapai varietas Vima III (2.44 g per tanaman), namun demikian bobot 100 biji terbesar dicapai oleh varietas Kutilang sebesar 7,78 g (Tabel 4). Perbedaan karakter hasil biji antar varietas dipengaruhi perbedaan karakteristik hasil antar ketiga variietas sebagai ekspresi genetik yang berbeda antar varietas, dimana Vima 3 mempunyai karakteristik jumlah biji per tanaman lebih banyak dibandingkan varietas Vima 2 dan Kutilang. Tingkat produktivitas Vima III tertinggi lebih ditunjang oleh jumlah polong dan jumlah biji per polong yang lebih tinggi dibandingkan Kutilang maupun Vima II, meskipun bobot 100 biji lebih rendah dibanding Kutilang. Ukuran biji pada varietas kutilang yang lebih besar menyebabkan bobot 100 biji lebih berat dibanding Vima II dan Vima III

Selanjutnya perlakuan cekaman kekeringan tidak berpengaruh terhadap parameter jumlah biji per polong tetapi berpengaruh terhadap bobot biji pertanaman dan bobot 100 biji (Tabel 5 dan 6), dimana jumlah biji per polong terbanyak pada perlakuan kadar lengas tanah kapasitas lapang $(9,5)$ dan paling sedikit pada kadar lengas tanah 50\% kapasitas lapang $(9,03)$. Bobot biji per tanaman terbesar pada perlakuan kapasitas lapang $(2,49 \mathrm{~g})$ dan paling kecil pada perlakuan cekaman kekeringan 50 persen kapasitas lapang (1,95 g), sedangkan bobot kering 100 biji yang paling banyak terdapat pada perlakuan kapasitas lapang (7,76 g) dan terkecil terdapat pada perlakuan cekaman kekeringan 50 persen kapasitas lapang (6,55 g). Cekaman kekeringan pada fase generatif menyebabkan hasil yang menurun seiring dengan semakin meningkatnya cekaman kekeringan (Andi, 2016). Menurut Anjum, et. al., (2011) pengaruh langsung cekaman kekeringan terutama terhadap apparatus fotosintesis dan pertukaran gas yang disebabkan oleh penurunan luas daun, kerusakan pada aparatus fotosintesis, oksidasi kloroplas, serta perubahan struktur pigmen dan protein.
Tabel 4. Pengaruh Cekaman Kekeringan dan Varietas Kacang Hijau Terhadap Jumlah Biji Per Polong.

\begin{tabular}{lcccc}
\hline \multirow{2}{*}{ Cekaman } & \multicolumn{4}{c}{ Varietas } \\
\cline { 2 - 5 } & Kutilang & Vima II & Vima III & Rerata \\
\hline $\begin{array}{l}\text { Kapasitas } \\
\text { Lapang }\end{array}$ & 9 & 8,64 & 10,86 & $9,5 \mathrm{a}$ \\
$\begin{array}{l}75 \% \text { kapa- } \\
\text { sitas lapang }\end{array}$ & 8,73 & 9,15 & 10,31 & $9,4 \mathrm{a}$ \\
$\begin{array}{l}\text { 50 \% kapa- } \\
\text { sitas lapang }\end{array}$ & 7,8 & 8,6 & 10,71 & $9,03 \mathrm{a}$ \\
\hline \multicolumn{1}{c}{ Rerata } & $8,51 \mathrm{~b}$ & $8,8 \mathrm{~b}$ & $10,62 \mathrm{a}$ \\
\hline
\end{tabular}

Keterangan: Angka-angka yang diikuti oleh huruf yang sama pada kolom yang sama menunjukkan tidak berbeda nyata menurut Uji DMRT pada taraf kepercayaan $95 \%$

Tabel 5. Pengaruh Cekaman Kekeringan san Varietas Kacang Hijau Terhadap Bobot Biji Per Tanaman (g).

\begin{tabular}{|c|c|c|c|c|}
\hline \multirow[t]{2}{*}{ Cekaman } & \multicolumn{3}{|c|}{ Varietas } & \multirow[b]{2}{*}{ Rerata } \\
\hline & Kutilang & Vima II & Vima III & \\
\hline $\begin{array}{l}\text { Kapasitas } \\
\text { Lapang }\end{array}$ & 2,41 & 2,28 & 2,77 & $2,49 a$ \\
\hline $\begin{array}{l}75 \% \text { kapa- } \\
\text { sitas lapang }\end{array}$ & 2,02 & 2,31 & 2,39 & $2,24 \mathrm{~b}$ \\
\hline $\begin{array}{l}50 \% \text { kapa- } \\
\text { sitas lapang }\end{array}$ & 1,88 & 1,81 & 2,16 & $1,95 \mathrm{~b}$ \\
\hline Rerata & $2,1 \mathrm{a}$ & $2,13 \mathrm{a}$ & $2,44 \mathrm{~b}$ & \\
\hline
\end{tabular}

Keterangan: Angka-angka yang diikuti oleh huruf yang sama pada kolom yang sama menunjukkan tidak berbeda nyata menurut Uji DMRT pada taraf kepercayaan $95 \%$.

Tabel 6. Pengaruh Cekaman Kekeringan dan Varietas Kacang Hijau terhadap Bobot 100 Biji (g)

\begin{tabular}{lcccc}
\hline \multirow{2}{*}{ Cekaman } & \multicolumn{4}{c}{ Varietas } \\
\cline { 2 - 4 } & Kutilang & Vima II & Vima III & Rerata \\
\hline $\begin{array}{l}\text { Kapasitas } \\
\text { Lapang }\end{array}$ & 8,45 & 7,38 & 7,45 & $7,76 \mathrm{a}$ \\
$\begin{array}{l}75 \% \text { kapa- } \\
\text { sitas lapang }\end{array}$ & 8,09 & 6,89 & 6,99 & $7,32 \mathrm{a}$ \\
$\begin{array}{l}50 \% \text { kapa- } \\
\text { sitas lapang }\end{array}$ & 6,81 & 6,30 & 6,53 & $6,55 \mathrm{~b}$ \\
\hline \multicolumn{1}{c}{ Rerata } & $7,78 \mathrm{a}$ & $6,86 \mathrm{~b}$ & $6,99 \mathrm{~b}$ \\
\hline
\end{tabular}

Keterangan: Angka-angka yang diikuti oleh huruf yang sama pada kolom yang sama menunjukkan tidak berbeda nyata menurut Uji DMRT pada taraf kepercayaan $95 \%$ 


\section{Kesimpulan dan Saran}

Cekaman kekeringan belum mempengaruhi perubahan karakter fisiologi dan biokimia tanaman, dimana penurunan $25 \%$ dari kapasitas lapang merupakan kondisi yang terbaik dilihat dari karakter luas daun. Penurunan kadar air tanah sampai 50 persen tidak berpengaruh terhadap klorofil a, klorofil b, kadar prolin daun dan laju asimilasi bersih tanaman kacang hijau. Varietas Vima III memiliki karakter kadar prolin tertinggi sehingga diduga varietas Vima III lebih tahan terhadap kekeringan.

\section{Ucapan Terima Kasih}

Penulis mengucapkan terimakasih sebesarbesarnya kepada Prof. Dr. Rifda Naufalin selaku Ketua LPPM UNSOED yang telah mendanai penelitian ini melalui skim Peningkatan Kompetensi TA 2018. Penulis juga mengucapkan terimakasih kepada Bintang Bustomi dan Riesky Apriliawan yang telah membantu pelaksanaan dan pengambilan data penelitian ini.

\section{Daftar Pustaka}

Andi, S. 2016. Respons Tanaman Kedelai Terhadap (Glycine max L.) Cekaman Kekeringan Paada Fase Vegetatif Dan Generatif. Tesis. Bogor: Program Pascasrjana, Institut Pertanian Bogor.

Anjum, S.A., Xiao-yu Xie, Long-chang Wang, Muhammad Farrukh Saleem, Chen Man and Wang Lei. 2011. Morphological, physiological and biochemical responses of plants to drought stress. African Journal of Agricultural Research 6(9): 2026-2032. doi: 10.5897/AJAR10.027.

Alexieva, V., I. Sergiev, S. Mapelli and E. Karanov. 2001. The effect of drought and ultraviolet radiation on growth and stress markers in pea and wheat. Plant, Cell and Environment 24: 1337-1344.

Ariyanto, S.E. 2010. Kajian dampak perubahan iklim terhadap produktivitas kacang hijau (Phaseolus radiatus L.) di lahan kering. 3(1): 1-10.

Baroowa, B., and N. Gogoi. 2013. Biochemical change in two Vigna spp. during drought and subsequent recovery. Int. J. Plant Physiol 18(4): 319-325. Doi: 10.1007/s40502-013-0048-5.

Fang, Y., and L. Xiong. 2015. General mechanisms of drought response and their application in drought resistance improvement in plant. Cell. Mol. Life Sci. 72: 673-689. Doi: 10.1007/s00018-014-1767-0.

Farooq, M., A. Wahid, N. Kobayashi, D. Fujita, and S.M.A. Basra. 2009. Plant drought stress: effects, mechanisms and management. Agron. Sustain. Dev. 29: 185-212. doi: 10.1051/agro:2008021.

Frederick, J.R., C.R. Camp, and P. J. Bauer. 2001. Drought-stress effects on branch and mainstem seed yield and yield components of determinate soybean. Crop Sci. 41:759-763.

Gardner, F.P, R.B. Pearce, \& R.L Mitchell.1991. Fisiologi Tanaman Budidaya. Terjemahan Herawati Susilo dan Subiyanto. UI Press, Jakarta. 428p.

Guntoro, W. dan Suhardjono. 2016. Respons tanaman kedelai (Glycine max L. Merr) terhadap jumlah air yang diberikan. Agritrop 14(2): 120-123.

Kasno, A. 2007. Kacang Hijau Alternatif yang Menguntungkan Ditanam di Lahan Kering. Tabloid Sinar Tani, 23 Mei 2007.

Kasno, A, N. Saleh, dan E. Ginting. 2008. Pengembangan pangan berbasis kacangkacangan dan umbi-umbian guna pemantapan ketahanan pangan nasional. Bul. Palawija 12: 43-51.

Kobraei, S., A. Etminan, R. Mohammadi, and S. Kobraee. 2011. Effects of drought stress on yield and yield components of soybean. Annals of Biological Research 2 (5):504-509.

Kurniawati, S., N. Khumaida, S.W. Ardie, N. Sri Hartati, dan E. Sudarmonowati. Pola akumulasi prolin dan poliamin beberapa aksesi tanaman terung pada cekaman kekeringan. J. Agron. Indonesia 42 (2) : 136 - 141.

Liu, F., M.N. Andersen, C.R. Jensen. 2003. Loss of pod set caused by drought stress in assosiated with water status and ABA content of reproductive structures in soybean. Funct Plant Biol 30: 271-280.

Liu, F., C.R. Jensen, M.N. Andersen. 2004. Drought Stress Effect on Carbohydrat Concentration in Soybean Leaves and Pods During Early Reproductive Development: Its Implication in Altering Pod Set. Field Crops Research 86 (2004) 1-13. 
Nikmatullah, N. 2010. Biosintesis etilen dan akumulasi prolin pada semanggi putih (Trifolium repens L.) cv. Kopu dalam kondisi cekaman air.Crop Agro 3(2): 77-87.

Palupi, E.R., dan Y. Dedywiryanto. 2008. Kajian karakter ketahanan terhadap cekaman kekeringan pada beberapa genotipe bibit kelapa sawit (Elaeis guineensis Jacq.). Bul. Agron. 36(1): 24 - 32.

Prasetiaswati, N., dan B.S. Radjit. 2011. Kajian dampak penerapan varietas kacang hijau vimai dan komponen teknologi pendukungnya di lahan sawah. Buana Sains (11)1: 17-24.

Proklamasiningsih, E., I.D. Prijambada, D. Rachmawati, R.P. Sancayaningsih. 2012. Laju fotosintesis dan kandungan klorofil kedelai pada media tanam masam dengan pemberian garam aluminium. Agrotrop, 2(1): 17-24.

Purbajanti, E.D., R.D. Soetrisno, E. Hanudin, \& S.P.S. Budhi. 2010. Penampilan fisiologi dan hasil rumput benggala (Panicum maximum Jacq.) pada tanah salin akibat pemberian pupuk kandang, gypsum dan sumber nitrogen. J. Ilmu-Ilmu Pertanian Indonesia 12(1) : 61-67.

Purwanto, dan T. Agustono. 2010. Kajian fisiologi tanaman kedelai pada berbagai kepadatan gulma teki dalam kondisi cekaman kekeringan. J. Agroland 17 (2) : 85 - 90.

Purwaningrahayu, R.D., Trustinah, M. Anwari., dan B.S. Radjit. 2011. Tanggap galur-galur kacang hijau terhadap cekaman kekeringan. Prosiding Seminar Hasil Penelitian Tanaman Aneka Kacang dan Umbi 2011. Balitkabi, Malang
Radjit, B.S. dan N. Prasetiaswati. 2012. Prospek kacang hijau pada musim kemarau di Jawa Tengah. Bul. Palawija 24: 57-68.

Rahbarian, R., R. Khavari-Nejad, A. Ganjeali, A. Bagheri, and F. Najafi. 2011. Dought stress effect on photosynthesis, chlorophyll fluorescence and water relation in tolerant and susceptible Chickpea (Cicer arietinum L) genotype. Acta Biologica Cracoviensia series Botanica 53(1): 47-56. Doi: 10.2478/v10182-011-0007-2.

Riduan, A., H. Aswidinnoor, J. Koswara, dan Sudarsono. 2005. Toleransi sejumlah kultivar kacang tanah terhadap cekaman kekeringan. Hayati 12(1): 28-34.

Sitompul, S.M., dan B. Guritno. 1995. Analisis Pertumbuhan Tanaman. Gadjah Mada University Press, Yogyakarta.

Suhartono, Saed S, Khoiruddin A. 2008. Pengaruh Interval Pemberian Air Terhadap Pertumbuhan dan Hasil Tanaman Kedelai (Glycine max L) pada Berbagai Jenis Tanah. Jurnal Embryo 5(1).

Taiz E, Zeiger L. 2002. Plant Physiology. Third Edition. Sinauer Associate Inc Publisher Sunderland, Massachusetts. 667

Trustinah, B.S. Radjit, N. Prasetiaswati, dan D. Harnowo. 2014. Adopsi varietas unggul kacang hijau di sentra produksi. Iptek Tanaman Pangan 9(1): 24-38.

Wang, J., R. Zheng, S. Bai, X. Gao, M. Liu, and W. Yan. 2015. Mongolian almon (Prunus mongolica Maxim): the morphophysiological, biochemical and transcriptomic response to drought stress. Plos One 10(4): e0124442. Doi:10.1371/journal.pone. 0124442. 